\begin{tabular}{lcl}
\hline INESEG \\
$\begin{array}{c}\text { INTERNATIONAL } \\
\text { ENGINEERING, } \\
\text { SCIENCE AND } \\
\text { EDUCATION GROUP }\end{array}$ & Middle East Journal of Science \\
https://dergipark.org.tr/mejs
\end{tabular}

Research Article

\title{
ESSENTIAL ELEMENTS AND HEAVY METAL LEVELS IN SHEEP MILK AND ITS DAIRY PRODUCTS
}

\author{
Serap KILIÇ ALTUN ${ }^{1 *}$ Mehmet Emin AYDEMIR ${ }^{1 \text { (I) }}$ \\ ${ }^{1 *}$ Harran University, Veterinary Faculty, Department of Food Hygiene and Technology, Şanlıurfa, Turkey \\ * Corresponding author; skilicaltun@ harran.edu.tr
}

\begin{abstract}
Milk and various dairy products are among the basic foods used in nutrition. However, milk and dairy products can contain many environmental pollutants such as pesticides, detergents, drug residues, heavy metals that may pose technological risks and are dangerous for human health. The aim of this study is to reveal the change of the amounts of essential elements and heavy metals in sheep's milk, yoghurt, buttermilk, and butter which are produced from the same milk. For this purpose, yoghurt, buttermilk, and butter were made from sheep's milk. Then, in milk and dairy products, Sodium (Na), Magnesium (Mg), Potassium (K), Manganese (Mn), Copper (Cu), Zinc (Zn), Arsenic (As), Selenium (Se) ), Cadmium ( $C d)$, Lead $(P b)$ amounts were examined by ICP-MS. The amount of $A s, C d, P b$ in all samples were determined under the limit of detection (LOD). The amounts of $\mathrm{Na}, \mathrm{Mg}, \mathrm{K}, \mathrm{Mn}, \mathrm{Cu}, \mathrm{Zn}$, Se in milk were determined as 785, 92, 1537, 30,8, 73,5, 2683,5, 381,5 ppb, respectively. The amounts of $\mathrm{Na}, \mathrm{Mg}, \mathrm{K}, \mathrm{Mn}, \mathrm{Cu}, \mathrm{Zn}$, Se in yogurt were determined as 554,5, 121,5, 1516,5, 29,3, 71,5, 3692, 405 ppb, respectively. The amounts of $\mathrm{Na}, \mathrm{Mg}, \mathrm{K}, \mathrm{Mn}, \mathrm{Cu}, \mathrm{Zn}$, and Se in buttermilk were determined as 40175, 56,5, 553,5, 111,5, 1230, 2506,5, $447 \mathrm{ppb}$, respectively. The amounts of $\mathrm{Na}, \mathrm{Mg}, \mathrm{K}, \mathrm{Mn}, \mathrm{Cu}, \mathrm{Zn}$, Se in butter were determined as 98,2, 31,7, 223,1, 10,1, 24,6, 203,5, 282,5 ppb, respectively. According to these data, changes in the amount of essential elements were observed when milk was transformed into its products. It was determined that there were no heavy metals in sheep milk and products grown in this region.
\end{abstract}

Keywords: Sheep milk, Dairy product, Element, Heavy metal, ICP-MS

Received: October 14, $2020 \quad$ Accepted: December 22, 2020

\section{Introduction}

Milk is produced in the milk glands of female mammals to feed their offspring. Various foods derived from milk are called "dairy products" such as cheese, cream, yoghurt, buttermilk, butter [1]. Milk and dairy products are among the basic foods used in human nutrition. Milk and dairy products are among the foods that are highly preferred by consumers because they have high biological values rich in nutrients, are thought to have little health risk, and are especially easily accessible. However, milk and dairy products may contain many environmental pollutants such as pesticides, detergents, drug residues, heavy metals that may pose technological risks and are dangerous for human health [2]. 
The heavy metal term is a general nomenclature given to heavy metals with an atomic number greater than 20 or a volume occupying one cubic centimeter more than five grams [3]. Heavy metals tend to accumulate in the tissues of the mammalian body, reaching toxic values over time and may cause serious health problems [4]. Heavy metals enter the human body through digestion, respiration, and skin. Acute, subacute and chronic intoxication symptoms (such as microcytic anemia, liver necrosis, memory retardation, speech, and voice disorders) occur depending on overdose, frequency, and duration of intake [5].

The level of elements found in milk and dairy products is very important due to their essential or toxic effects. For example, although $\mathrm{Cd}, \mathrm{As}, \mathrm{Pb}$ are toxic, $\mathrm{Cu}, \mathrm{Se} \mathrm{Zn}, \mathrm{Cr}, \mathrm{Na}, \mathrm{Mg}, \mathrm{Mn}$ are essential and are toxic only at high doses. Among the elements that have negative effects on human health, $\mathrm{Pb}$, As and $\mathrm{Cd}$ are the most dangerous [6,7]. Considering that milk and dairy products are one of the basic foods, the possibility of having high amounts of lead, cadmium, copper, and zinc residues in milk poses a serious risk. Children are more sensitive to heavy metals than adults. Because heavy metals accumulate in the tissues and very small amounts of milk can cause serious effects on the health of children. For example, slowing down in mental development, decrease in concentration can negatively affect kidney and heart health $[8,9]$.

Heavy metal contamination of milk and dairy products; The feed consumed by the animals from which milk is obtained can pass directly to the milk as a result of contamination with the animal through the water they drink and the air they breathe [10]. In addition, contamination can occur from machinery and equipment that come into contact with dairy products during the production and storage of milk and dairy products. Contamination may occur during technological processes or from metal containers and operational water used to preserve milk and milk products. Even if there is no heavy metal contamination in the milk to be used in technology, heavy metal can be detected after milk is processed (cheese, yogurt, buttermilk, butter). This is the result of metals in the composition of containers used in the production of acidic dairy products, dissolving into the product. The main elements in water and metallic contamination used in the business are copper, zinc, iron, tin, lead, arsenic, and cadmium [11, 12].

Akin et al. (2003) reported that the high level of aluminum they detected in raw milk may be caused by tools and equipment made of aluminum metal in addition to the feed consumed by animals [13]. Yuzbasi (2001) found that the amount of lead in the milk to be processed into cheddar cheese decreased significantly in cheddar cheeses after production, there was no change in the amount of copper, but the amount of cadmium increased [10]. Temurci and Güner. (2006) reported that when they examined heavy metal levels in milk and cheese obtained from these milks, they found that aluminum, chromium, copper, and iron amounts in cheese samples were higher than milk samples [14]. In this study, we aimed to demonstrate the change of essential element and heavy metal amounts in sheep's milk, yoghurt, buttermilk, and butter that we produce from this milk with the ICP-MS device.

\section{Material Method}

In this study, samples of milk belonging to ivesi breed sheep taken from the farm of Harran University, and samples of yoghurt, buttermilk, and butter produced from this milk formed the material of the study (Figure 1-3) [15]. 


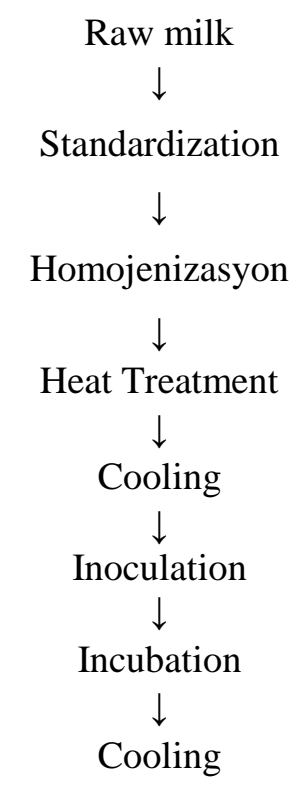

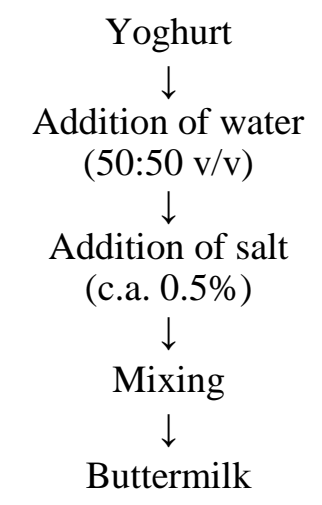

Figure 2. Buttermilk production stages

Figure 1. Yoghurt production stages

After dairy products are prepared in the laboratory, 1 gram of milk, cheese, yoghurt, and butter samples were weighed after the homogenization process and taken into the sample containers of the microwave device. $4 \mathrm{~mL}$ of $65 \%$ (v/ v) nitric acid (HNO3) and $2 \mathrm{~mL}$ of $30 \%(\mathrm{v} / \mathrm{v}$ ) hydrogen peroxide $(\mathrm{H} 2 \mathrm{O} 2)$ were added with a pipette and placed in the microwave device. The samples were burned in the microwave device with the predetermined program (Table 1). After burning the samples cooled, they were taken into sterile tubes and diluted with ultrapure water.

Table 1. Burning process steps in microwave device

\begin{tabular}{|c|c|c|}
\hline Step & Temperature $\left({ }^{\circ} \mathbf{C}\right)$ & Time (min) \\
& & \\
\hline 1 & 90 & 8 \\
\hline 2 & 170 & 10 \\
\hline 3 & 210 & 25 \\
\hline
\end{tabular}

Elemental and heavy metal analyzes of the samples were performed with the Agilent brand, 7500ce series ICP-MS (Tokyo, Japan) device in the Mersin University Advanced Technology Education, Research and Application Center laboratory.

\section{Results and Discussion}

In this study, the element and heavy metal amount of each sample analyzed by ICP-MS is shown in Table 2. and Figure 4. 
Middle East Journal of Science (2020) 6(2):94-103 https://doi.org/10.23884/mejs.2020.6.2.06

Table 2. The element and heavy metal content of sheep milk and its dairy products

\begin{tabular}{|l|l|l|l|l|}
\hline Element & Milk & Yoghurt & Buttermilk & Butter \\
\hline Na (ppb) & 785 & 554.5 & 40175 & 98.2 \\
\hline Mg (ppb) & 92 & 121.5 & 56.5 & 31.7 \\
\hline K (ppb) & 1537 & 1516.5 & 553.5 & 223.1 \\
\hline Mn (ppb) & 30.8 & 29.3 & 111.5 & 10.1 \\
\hline Cu (ppb) & 73.5 & 71.5 & 1230 & 24.6 \\
\hline Zn (ppb) & 2683.5 & 3692 & 2506.5 & 203.5 \\
\hline As (ppb) & $<$ LOD & $<$ LOD & $<$ LOD & $<$ LOD \\
\hline Se (ppb) & 381.5 & 405 & 447 & 282.5 \\
\hline Cd (ppb) & $<$ LOD & $<$ LOD & $<$ LOD & $<$ LOD \\
\hline Pb (ppb) & $<$ LOD & $<$ LOD & $<$ LOD & $<$ LOD \\
\hline
\end{tabular}




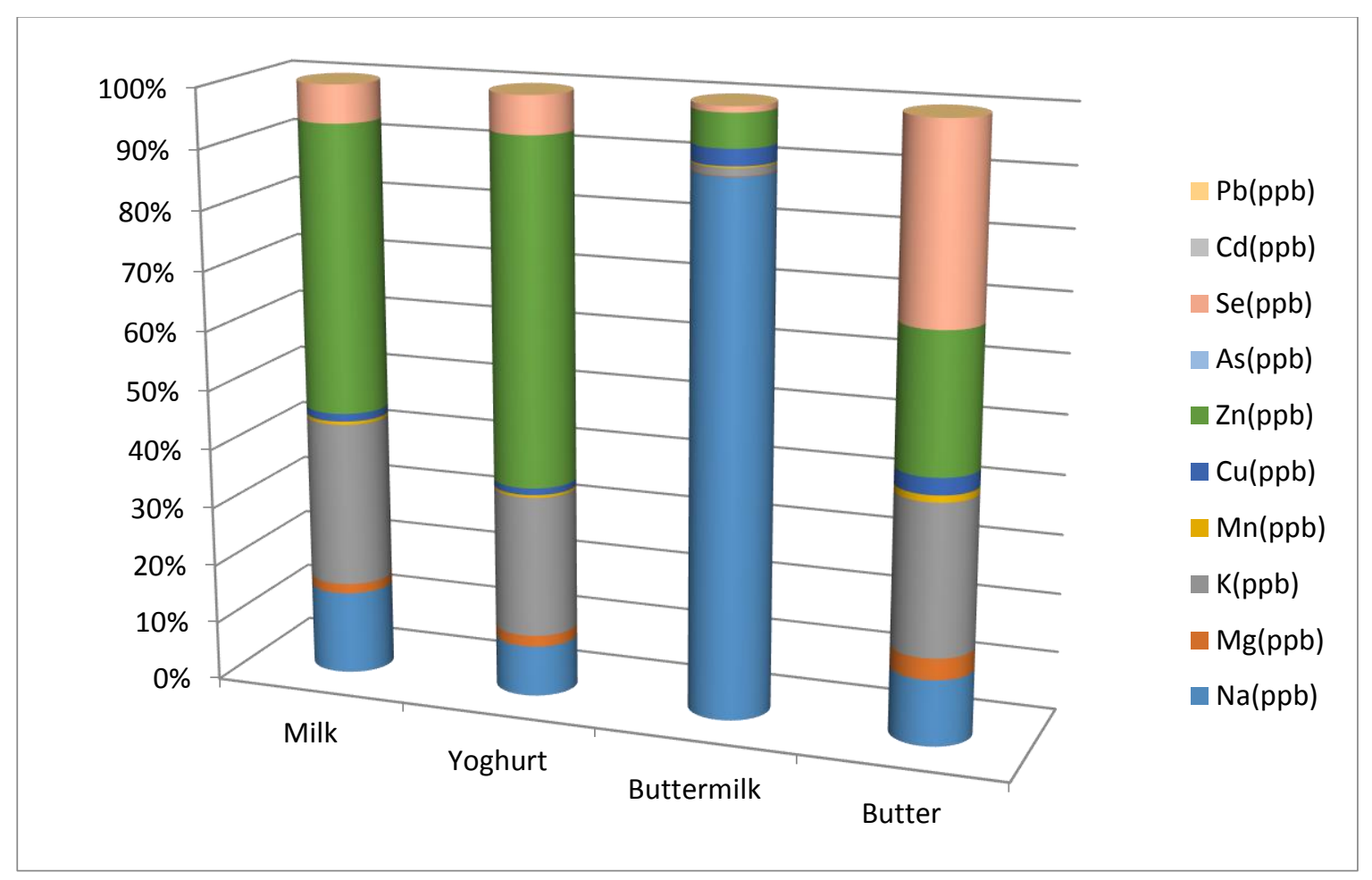

Figure 4. The element and heavy metal content of sheep milk and its dairy products

Micronutrients such as copper, magnesium, potassium, and zinc are essential for many biological functions. The deficiencies of such elements in the body contribute significantly to the emergence of many diseases. However, if these elements are found in foods at higher levels, they can have negative effects on human health [16]. The trace element content and heavy metal contents of milk and dairy products may vary depending on the lactation stage, the nutritional status of the animal, environmental and genetic factors, and possible contamination during production [17]. In this study we conducted, firstly, the mineral and heavy metal amounts in milk and then in dairy products produced from that milk were examined. There was a change in the amount of minerals seen (yoghurt, buttermilk, butter) (Table 2, Figüre 4.).

$\mathrm{Na}$ has many beneficial effects in the body, such as osmotic pressure, electrolyte balance, acidbase balance, and electrochemical impulse transmission across nerve and muscle membranes [18]. There is also some $\mathrm{Na}$ in milk and dairy products. However, the amount of $\mathrm{Na}$ in milk and dairy products varies according to the lactation period, nutritional status and the process applied to the milk. In a study conducted by Güler (2007), heavy metal analyzes were made on yoghurts produced from goat milk and goat milk collected from Hatay. Na levels were determined as 433 ppm for raw milk, 520 ppm for strained yogurt, and $5147 \mathrm{ppm}$ for salted strained yogurt, respectively [19]. In our study, the amount of $\mathrm{Na}$ was $785 \mathrm{ppb}$ in milk, 554,5 ppb in yogurt, $40175 \mathrm{ppb}$ in buttermilk, and 98,2 ppb in butter. Na amount was determined in the highest buttermilk. The reason for the high amount of $\mathrm{Na}$ in buttermilk is due to the addition of $\mathrm{NaCl}$ during construction.

$\mathrm{Mg}$ has many functions involved in more than 300 reactions in the body. $\mathrm{Mg}$ is found in most foods. It is a good source of $\mathrm{Mg}$ in milk and dairy products. There is about $100 \mathrm{mg}$ of $\mathrm{Mg}$ in one liter [20]. The amount of Mg varies according to the lactation period, the animal's diet and the process applied 
to the milk. In a study conducted by Güler (2007), heavy metal analyzes were made on yoghurts produced from goat milk and goat milk collected from Hatay. $\mathrm{Mg}$ levels were determined as $510 \mathrm{ppm}$ for raw milk, $587 \mathrm{ppm}$ for strained yogurt, and $838 \mathrm{ppm}$ for salted strained yogurt, respectively [19]. In our study, the amount of $\mathrm{Mg}$ was $92 \mathrm{ppb}$ in milk, 121,5 ppb in yoghurt made from milk, 56,5 ppb in buttermilk, and 31,7 ppb in butter. The amount of $\mathrm{Mg}$ was found the most in yogurt and the least in butter.

K has many beneficial effects osmotic pressure, electrolyte balance, acid-base balance, nerve impulses, contraction of the heart and other muscles, protein synthesis, conversion of glucose into glycogen in the body [18]. Therefore, $\mathrm{K}$ should be taken from outside with food. The amount of $\mathrm{K}$ changes according to the lactation period, the animal's diet and the process applied to the milk. In a study conducted by Güler (2007), heavy metal analyzes were made on yoghurts produced from goat milk and goat milk collected from Hatay. K levels were determined as $409 \mathrm{ppm}$ for raw milk, $511 \mathrm{ppm}$ for strained yogurt, and $554 \mathrm{ppm}$ for salted strained yogurt, respectively [19]. In our study, the amount of K was $1537 \mathrm{ppb}$ in milk, 1516,5 ppb in yoghurt made from milk, 553,5 ppb in buttermilk, and 223,1 ppb in butter. $\mathrm{K}$ amount was determined mostly in yoghurt. The low amount of $\mathrm{K}$ element in butter and buttermilk suggests that it may be due to the production process.

Mn participates in cofactor, reproduction, and bone structure in many enzymatic reactions in the body and is necessary because it has many functions such as regulating brain functions. Therefore, $\mathrm{Mn}$ should be taken from outside with food [18]. It contains some Mn element in milk and dairy products. The amount of Mn varies according to the lactation period, the animal's feeding, and the process applied to the milk. Enb et al. (2009), in their study with buffalo and cow milk, determined the amount of Mn in buffalo milk as $0.076 \mathrm{mg} / \mathrm{kg}$ and the amount of $\mathrm{Mn}$ in cow milk as $0.056 \mathrm{mg} / \mathrm{kg}$. In the same study, the highest amount of Mn in dairy products such as cream and butter was determined as $0.316 \mathrm{mg} / \mathrm{kg}$ in butter and $0.234 \mathrm{mg} / \mathrm{kg}$ in cream [21]. Kaya et al. (2008) reported metal concentrations in yoghurt made from cow's milk in a controlled environment as $0.01-0.179 \mathrm{mg} / \mathrm{kg}$ for Mn [22]. In our study, the amount of Mn was 30,8 ppb in milk, 29,3 ppb in yoghurt made from milk, 11,5 ppb in buttermilk, and $10.1 \mathrm{ppb}$ in butter. While Mn amounts were higher in milk and yoghurt, the amount of $\mathrm{Mn}$ in buttermilk and butter decreased.

$\mathrm{Cu}$ is required as a trace element necessary for adequate growth, cardiovascular system, lungs, neuronendocrine function, and iron metabolism [23] Excess Cu taken into the body due to contamination or other reasons may cause poisoning effect and cause hypercoupremia. Generally, the Cu level contained in milk is at minimum levels but With subsequent contamination, $\mathrm{Cu}$ in milk and dairy products can be seen at maximum level [24]. Kaya et al. (2008) reported metal concentrations in yogurt made from cow's milk in a controlled environment as $0.011-0.498 \mathrm{mg} / \mathrm{kg}$ for $\mathrm{Cu}$ [22]. Temurci and Güner. (2006) reported that when they examined heavy metal levels in milk and cheese obtained from these milks, the amount of $\mathrm{Cu}$ in cheese samples was higher than in milk samples [14]. Yuzbasi (2001) reported that the amount of $\mathrm{Cu}$ in milk to be processed into cheddar cheese does not change in cheddar cheese after production [10]. Gördes Baş (2020) reported that the $\mathrm{Cu}$ amount in yoghurt and buttermilk offered for consumption was $0.03 \mathrm{mg} / \mathrm{kg}$ in yoghurt and $0.01 \mathrm{mg} / \mathrm{kg}$ in buttermilk [25]. In a study conducted by Kan and Küçükkurt (2018), Cu amount was reported as $0.09 \mathrm{mg} / \mathrm{kg}$ in cream and $0.02 \mathrm{mg}$ / $\mathrm{L}$ in cream milk [26]. In this study we conducted, $\mathrm{Cu}$ amount was 73,5 ppb in milk, 71,5 ppb in yoghurt made from milk, $1230 \mathrm{ppb}$ in buttermilk, and 24,6 ppb in butter. The high amount of $\mathrm{Cu}$ in buttermilk 
is thought to be due to the use of metal containers in the production of buttermilk and adding water from the outside. The probable reason for the high $\mathrm{Cu}$ content in buttermilk is due to the added salt or water.

$\mathrm{Zn}$ is involved in many physiological processes such as nucleic acid and protein synthesis, cellular replication, insulin secretion, sexual maturation, and strengthening of the immune system [27]. Enb et al. (2009) found the $\mathrm{Zn}$ value in milk as 4,350 mg / kg, in yogurt 4,059 mg / $\mathrm{kg}$, in cream 19,570 $\mathrm{mg} / \mathrm{kg}$ and in butter $29,363 \mathrm{mg} / \mathrm{kg}$ in their heavy metal analysis by collecting milk from buffalo and cow milk and obtaining dairy products [21]. Gördes Baş (2020) reported that the amount of $\mathrm{Zn}$ in yoghurt and buttermilk offered for consumption is $3.05 \mathrm{mg} / \mathrm{kg}$ in yoghurt and $1.66 \mathrm{mg} / \mathrm{kg}$ in buttermilk [25]. In a study conducted by Güler (2007), heavy metal analyzes were made on yoghurts produced from goat milk and goat milk collected from Hatay. Zn levels were determined as $4.68 \mathrm{ppm}$ for raw milk, $6.85 \mathrm{ppm}$ for strained yogurt, and $9.00 \mathrm{ppm}$ for salted strained yogurt, respectively [19]. In a study by Kan and Küçükkurt (2018), the amount of $\mathrm{Zn}$ was reported as $8.27 \mathrm{mg} / \mathrm{kg}$ in cream and $2.37 \mathrm{mg} / \mathrm{L}$ in skim milk [26]. In this study, the amount of Zn was determined as 2683,5 ppb in milk, $3692 \mathrm{ppb}$ in yogurt made from milk, 2506,5 ppb in buttermilk, and $203.5 \mathrm{ppb}$ in butter. The $\mathrm{Zn}$ amount was found in the highest yogurt and the lowest in butter. As the $\mathrm{Zn}$ element attaches to the casein micelles in yoghurt production, it was detected at a higher rate in yoghurt.

Se plays an important role in immunity, antioxidant system, DNA synthesis, and DNA repair. The recommended daily intake of Se is $55 \mu \mathrm{g}$. It is an important source of Se in milk and dairy products [20]. Setting et al. (2007) investigated some heavy metals in various dairy products and found the highest Se value in Tulum cheese with $0.434 \mathrm{mg} / \mathrm{kg}$ and then in butter with $0.315 \mathrm{mg} / \mathrm{kg}$ [28]. In a study conducted by Güler (2007), heavy metal analyzes were made on yoghurts produced from goat milk and goat milk collected from Hatay. Se levels were determined as $7.59 \mathrm{ppm}$ for raw milk, $10.77 \mathrm{ppm}$ for strained yogurt, and $12.20 \mathrm{ppm}$ for salted strained yogurt, respectively [19]. In a study by Kan and Küçükkurt (2018), the amount of Se was reported as $0.94 \mathrm{mg} / \mathrm{kg}$ in skim milk and $0.17 \mathrm{mg} / \mathrm{L}$ in skim milk [26]. In our study, the amount of Se was $381,5 \mathrm{ppb}$ in milk, $405 \mathrm{ppb}$ in yogurt made from milk, $447 \mathrm{ppb}$ in buttermilk, and 282,5 ppb in butter.

The amounts of Se in all samples were determined at close levels.

Since heavy metals cause acute and chronic health problems, national and international food organizations have introduced regulations to prevent contamination. However, in the communiqué of the Turkish Food Codex on determining the maximum levels of certain contaminants in foodstuffs [29], the highest acceptable values for milk and dairy products were determined as $0.020 \mathrm{mg} / \mathrm{kg}$ for $\mathrm{Pb}$, but no limit was specified for other metals. In this study, the amounts of $\mathrm{Pb}, \mathrm{As}$ and $\mathrm{Cd}$ in milk, yoghurt, buttermilk, and butter were analyzed. These heavy metals were not detected in any of the samples in the analysis results.

The presence of $\mathrm{Pb}$ in milk and dairy products is from environmental sources (atmosphere, vehicle exhausts, urban waste, etc.). Since $\mathrm{Pb}$ is toxic and has negative effects on human health, the Codex Alimentarius Commission [30] determined the $\mathrm{Pb}$ amount at the level of $0.02 \mathrm{mg} / \mathrm{kg}$ for milk and dairy products. Also, The Turkish Food Codex states that the highest acceptable $\mathrm{Pb}$ for milk and dairy products is $0.020 \mathrm{mg} / \mathrm{kg}$ [29]. In a study conducted by Güler (2007), heavy metal analyzes were made on yoghurts produced from goat milk and goat milk collected from Hatay. $\mathrm{Pb}$ levels were determined as $0.06 \mathrm{ppm}$ for raw milk, $0.11 \mathrm{ppm}$ for strained yoghurt, and 1,3 ppm for salted strained yogurt, respectively [19]. Kaya et al. (2008) reported metal concentrations in yogurt made from cow's milk in a controlled environment as $0.019-0.126 \mathrm{mg} / \mathrm{kg}$ for $\mathrm{Pb}$ [22]. In a study conducted by Hernandez and Park 
(2014), they reported the $\mathrm{Pb}$ amount of 3 different yoghurts made from goat milk obtained from a market as 4,003-4,280ppm [31]. Coni et al. (1999) in a study conducted in Italy; $\mathrm{Pb}$ amount is $0.006 \pm 0.003$ ppm in sheep milk, $0.016 \pm 0.006 \mathrm{ppm}$ in curd obtained from sheep milk, $0.003 \pm 0.001 \mathrm{ppm}$ in whey obtained from sheep's milk, $0.019 \pm 0.006 \mathrm{ppm}$ in Pecorino cheese obtained from sheep milk, 0.002 in Ricatta cheese obtained from sheep milk. It has been reported as \pm 0.001 [32]. Yuzbasi (2001) reported that the amount of $\mathrm{Pb}$ in the milk to be processed into cheddar cheese decreased significantly in postproduction cheddar cheese [10]. In a study by Kan and Küçükkurt (2018), it was reported that the amount of $\mathrm{Pb}$ shifts and the average values are the same in under-cream milk, while the standard deviation and maximum value are higher in under-cream milk [26]. Gördes Baş (2020) reported that he did not detect $\mathrm{Pb}$ in yoghurt and buttermilk offered for consumption [25]. In our study, the amount of $\mathrm{Pb}$ was found below the detection limits ( $<\mathrm{LOD})$ in milk and yoghurt made from milk, buttermilk, and butter.

$\mathrm{Cd}$ can contaminate milk and dairy products from the environment (soil, fertilizer, atmosphere). It is considered the most important food contaminant. $\mathrm{Cd}$ is important because it shows high toxicity and has negative effects on human health (8). Turkish Food Codex does not set any limit for Cd. In a study conducted by Güler (2007), heavy metal analyzes were made on yoghurts produced from goat milk and goat milk collected from Hatay. Cd levels were determined as $0.63 \mathrm{ppm}$ for raw milk, 1.01 ppm for strained yoghurt, and $1.00 \mathrm{ppm}$ for salted strained yogurt, respectively [19]. In a study conducted by Hernandez and Park (2014), they reported the Cd amount of 3 different yoghurts made from goat milk obtained from a supermarket as 0.614-0.700 ppm [31]. Coni et al. (1999) in a study conducted in Italy; The amount of Cd in sheep's milk is $0.058 \pm 0.019 \mathrm{ppm}$. It has been reported as 0.048 $\pm 0.016 \mathrm{ppm}$ in curd obtained from sheep milk, $0.076 \pm 0.035 \mathrm{ppm}$ in whey obtained from sheep milk, $0.025 \pm 0.009 \mathrm{ppm}$ in Pecorino cheese obtained from sheep milk, and $0.043 \pm 0.013 \mathrm{ppm}$ in Ricatta cheese obtained from sheep milk [32]. Yuzbasi (2001) reported that the amount of $\mathrm{Cd}$ in the milk to be processed into cheddar cheese increased in cheddar cheese after production [10]. In a study by Kan and Küçükkurt (2018), the amount of Cd in cream and cream milk was found below the detectable value [26]. Gördes Baş (2020) reported that he did not detect $\mathrm{Pb}$ in yoghurt and buttermilk offered for consumption [25]. In this study we conducted, the amount of Cd was found below the detection limits $(<\mathrm{LOD})$ in milk and yoghurt, buttermilk and butter made from milk.

As it is common in nature and increasing exposure to environmental arsenic today, high arsenic content in some products has increased. As is also contaminated with milk and dairy products from the environment (1). In a study by Kan and Küçükkurt (2018), the amount of As was reported as $0.14 \mathrm{mg} / \mathrm{kg}$ in skim milk and $0.04 \mathrm{mg} / \mathrm{L}$ in skim milk [26]. In a study conducted by Güler (2007), heavy metal analyzes were made on goat milk collected from Hatay and yoghurts produced from goat milk [19]. Arsenic has not been detected in any product. Gördes Baş (2020) reported that he did not detect As in yoghurt and buttermilk offered for consumption [25]. In our study, the amount of As was found below the detection limits $(<\mathrm{LOD})$ in yoghurt, buttermilk, and butter made from milk and milk.

\section{Conclusion}

According to these data, changes in the amount of essential elements were observed when milk was transformed into its products. It was determined that there were no heavy metals in sheep milk and products grown in this area. This study shows that sheep's milk and products can contribute significantly to the supply of elements in the human diet. It also provides important information on essential elements 
and heavy metal concentration about the safety and quality standards of sheep's milk, yoghurt, buttermilk, and butter.

The compliance to the Research and Publication Ethics: This study was carried out in accordance with the rules of research and publication ethics.

\section{Acknowledgment}

This study was presented as an oral presentation at the IV. International Eurasia Congress on Scientific Researches and Recent Trends-VII December 7-8, 2020 in Bakü, Azerbaijan.

\section{References}

$\lceil 1\rceil$ İstanbulluoğlu, H., Oğur, R., Tekbaș, Ö. F., Bakır, B. "Süt ve süt ürünlerinde ağır metal kirliliği”, Türkiye Klinikleri Tip Bilimleri Dergisi, 33(2), 410-419, 2013.

[2] Licata, P., Trombetta, D., Cristanı, M., Giofre, F., Martıno, D., Calo, M., Naccarı, F. "Levels of "toxic" and "essential" metals in samples of bovine milk from various dairy farms in Calabria", Italy. Environ Int. 30(1), 1-6, 2004.

[3] Agarwal, S.K., Heavy Metal Pollution. Vol: 4 APH Publishing, 2009.

[4] Hernández, A.J., Gutiérrez-Ginés, M.J., Pastor, J., Ecology And Health In Risk Analysis Of Polluted Soils. Environmental health risk. WIT Press, Southampton, pp. 257-268, 2009.

[5] Kaya, S., Prinçci, İ., Bilgili, A., Veteriner Hekimliğinde Toksikoloji. Medisan Yayınevi, 2002.

[6] Liu, Z.P., "Lead poisoning combined with cadmium in sheep and horses in the vicinity of non-ferrous metal smelters", The Science of the Total Environment, 309, 117-126, 2003.

[7] Martino, F.A.R., Sánchez, M.L.F., Medel, A, S., "Total determination of essential and toxic elements in milk whey by double focusing ICP-MS", Journal of Analytical Atomic Spectrometry, 15, 163-168, 2000.

[8] Girma, K., Tilahun, Z., Haimanot, D., "Review on milk safety with emphasis on 1ts public health", World Journal of Dairy \& Food Sciences, 9(2), 166- 183, 2014.

[9] Hizel, S., Şanlı, C., "Çocuklarda beslenme ve kurşun etkileşimi”, Çocuk Sağllğ ve Hastalıkları Dergisi, 49, 333- 338, 2006

[10] Yüzbaşı, N., Kaşar Peynirinde Bazı Ağır Metallerin Düzeyi ve Prosesteki Değişimi, Doktora Tezi, Ankara Üniversitesi Ankara, Türkiye, 2001.

[11] Metin M., Süt Teknolojisi. Ege Üniversitesi Basımevi, 2001.

[12] Pečar, D., Slemnik, M., Goršek, A., "Testing the corrosion resistance of stainless steels during the fermentation of probiotic drink", J. Sci. Food Agric., 91(7), 1293-7, 2011.

[13] Akın, N., Ayar, A., Sert, D., Çalık, N., "Konya ilinin değişik bölgelerinden toplanan sütlerin ağır metal içerikleri üzerine bir araştırma" Süt Endüstrisinde Yeni Eğilimler Sempozyumu, İzmir, Türkiye, 2003, s. 355-358.

$\lceil 14\rceil$ Temurci, H., Güner, A., "Ankara'da tüketime sunulan süt ve beyaz peynirlerde ağır metal kontaminasyonu”, Atatürk Üniversitesi Veteriner Bilimleri Dergisi, 1(2), 20-28, 2006.

[15] Tekinsen, O.C., Tekinsen, K.K., Süt ve Süt Urunleri : Temel Bilgiler, Teknoloji, Kalite Kontrolu. Selcuk Universitesi Basimevi, 2005. 
[16] Kazi, T.G., Jalbani, N., Baig, J.A., Kandhro, G.A., Afridi, H.I., Arain, M. B., Shah, A.Q., "Assessment of toxic metals in raw and processed milk samples using electrothermal atomic absorption spectrophotometer", Food and Chemical Toxicology, 47(9), 2163-2169, 2009.

[17] Meshref, A.M., Moselhy, W.A., Hassan, N.E.H.Y., "Heavy metals and trace elements levels in milk and milk products", Journal of food measurement and characterization, 8(4), 381-388, 2014.

$\lceil 18\rceil$ Özturan, K., Atasever, M., "Süt ve ürünlerinde mineral maddeler ve ağır metaller", Atatürk Üniversitesi Veteriner Bilimleri Dergisi, 13(2), 229-241, 2018.

$\lceil 19\rceil$ Güler, Z., "Levels of 24 minerals in local goat milk, its strained yoghurt and salted yoghurt (tuzlu yoğurt”, Small Ruminant Research, 71(1-3), 130-137, 2007.

[20] Haug, A., Høstmark, A.T., Harstad, O.M., "Bovine milk in human nutrition-a review", Lipids in health and disease, 6(1), 25, 2007.

[21] Enb, A., Abou Donia, M.A., Abd-Rabou, N.S., Abou-Arab, A.A.K., El-Senaity, M.H., "Chemical composition of raw milk and heavy metals bahavior during processing of milk products", Global Veterinaria, 3 (3): 268 - 275, 2009.

[22] Kaya, G., Akdeniz, I., Yaman, M., "Determination of $\mathrm{Cu}, \mathrm{Mn}$, and $\mathrm{Pb}$ in yogurt samples by flame atomic absorption spectrometry using dry, wet, and microwave ashing methods", Atomic Spectroscopy, 29(3), 99-106, 2008.

[23] Sieber, R., Rehberger, B., Schaller, F., Gallmann, P., "Technological aspects of copper in milk products and health implications of copper", ALP Science, 493, 1-15, 2006.

$\lceil 24\rceil$ Yüzbașı, N., Sezgin, E., "Süt ve ürünlerindeki bazı metal kontaminasyonlarının toksikolojik etkileri”, Gida, (2), 121-122, 2002.

$\lceil 25\rceil$ Gördes Baş, H. Tüketime Sunulan Yoğurt Ve Buttermilklarda Ağır Metal Varlığının Araştırılması, Master's thesis, Afyon Kocatepe Üniversitesi, Afyon, Türkiye, 2020.

[26] Fahriye, K.A.N., Küçükkurt, İ., "Afyon manda kaymağı ve kaymakaltı sütlerinde bazı ağır metallerin ICP-MS ile araştırılması" Kocatepe Veteriner Dergisi, 11(4), 447-453, 2018.

[27] Vahčić, N., Hruškar, M., Marković, K., Banović, M., Barić, I.C., "Essential minerals in milk and their daily intake through milk consumption", Mljekarstvo/Dairy, 60(2), 77-85, 2010.

[28] Ayar, A., Sert, D., Akın, N., “ Konya'da tüketime sunulan süt ve süt ürünlerinin ağır metal içeriklerinin belirlenmesi”, Selcuk Journal of Agriculture and Food Sciences, 21 (41), 58 - 64, 2007.

[29] Türk Gıda Kodeksi: Gıda Maddelerindeki Bulaşanların Maksimum Yönetmeliği Hakkında Tebliğ. Tebliğ No: 2011- 28157, Ankara: Tarım ve Köy İşleri Bakanlığı, 2011.

[30] FAO/WHO- Food and Agriculture Organization/World Health Organization. Joint FAO/WHO food standards program: Codex committee on contaminants in foods (Editorial amendments to the general standard for contaminants and toxins in food and feed), sixth session, Maastricht, Netherlands, 26-30 march, 2012; CX/CF 12.6.11

[31] Hernandez, K., Park, Y.W., "Evaluation of 20 macro and trace mineral concentrations in commercial goat milk yogurt and its cow milk counterpart", Food and Nutrition Sciences, 5, 889-895, 2014.

$\lceil 32\rceil$ Con1, E., Bocca, B., Carol1, S., " Minor and trace element content of two typical Italian sheep dairy products", Journal of dairy research, 66(4), 589-598, 1999. 